\title{
Experimental Analysis of Jatropha Curcas Bio- Diesel for Optimum Blend Characteristics
}

\author{
N. Manikanda Prabu, Dr.S. Nallusamy and K. Thirumalai Rasu
}

\begin{abstract}
Increasing the fuel demand brings us to find out the various alternative solutions. Out of the various research activities, bio-diesel from various oil seeds is the major activity, which decides the future energy sources. Our previous researchers concluded that Jatropha oil is to be an alternate fuel for Compression ignition (C.I) engines and it has closer characteristics of diesel fuel. Still this oil cannot be utilized directly because of its physical and chemical characteristics. This article relating the Jatropha oil's physical and chemical characteristics, production techniques, how it is treated as an alternate for diesel fuel, comparison characteristics of Jatropha oil with conventional diesel fuel, finally the suitability parameters for diesel engine. The required fuel properties of biodiesel such as density, kinematic viscosity, calorific value, flash point, pour point, Cetane number, carbon residue and specific gravity were theoretically found. The various results with different blends of diesel and Jatropha oil (considering 0\%, 10\%, and 20\%) on single cylinder direct injection engine were experimentally found. Based on this, the engine characteristics such as brake thermal efficiency, brake specific fuel consumption and exhaust temperature are calculated manually. And also the emission characteristics are plotted with various aspects. These results indicating the optimum blend, which can be suitable for using as alternate fuel in diesel engine.
\end{abstract}

Keywords--- C.I Engine, Jatropha Oil Extraction\& Blend, Performance, Suitability Criteria

\section{INTRODUCTION}

$\mathrm{C}$ ONSIDERING the gradual decrease of petroleum reserve and environment impact there is a need of find out the various alternate fuels. In view of this, vegetable oil is a promising alternate solution because of eco-friendly, easily produced and renewable characteristics. Therefore, in recent years several researches have been studied to use vegetable oils as fuel in engines as biodiesel. Biodiesel is permanently thinned plant- or animal-based oil. Various vegetable oils, including palm oil, soybean oil, and sunflower oil, rapeseed

N. Manikanda Prabu, Assistant Professor, Department of Mechanical Engineering, Kodaikanal Institute of Technology, Kodaiknal, Tamilnadu, India, E-mail: mkp.thetrinity@gmail.com

Dr.S. Nallusamy, Principal, Kodaiknal Institute of Technology, Kodaikanal, Tamilnadu, India.

K. Thirumalai Rasu Assistant Professor, Department of Mechanical Engineering, Sri Subramanya college of Engineering and Technology, Palani, Tamilnadu, India.

DOI: 10.9756/BIJIEMS.4667 oil, and linseed oil, Jatropha oil have been used to produce biodiesel fuel and lubricants. Our concern in this article is about Jatropha bio-diesel. The Jatropha oil is slow-drying oil which is odorless and colorless when fresh, but becomes yellow on standing.

The oil content of Jatropha seed ranges to $55 \%$ by its weight [1]. The fatty acid composition of Jatropha classifies it as a linoleic or oleic acid type, which are unsaturated fatty acids [2]. The fatty acid composition of Jatropha oil consists of myristic, palmitic, stearic, arachidic, oleic and linoleic acids. The seeds and oil are toxic due to the presence of cursive and curcasive. The potential use of extracted oil from Jatropha curcas or as a blend with diesel has been studied [3]. The calorific value and cetane number of Jatropha curcas oil are comparable to diesel, but the density and viscosity are much higher [4].However, from the properties of this oil it is envisaged that the oil would be suitable as fuel oil.

\section{A. Why Jatropha?}

By considering the various vegetable oils, we prefer the Jatropha oil because of the following reasons.

- Availability of seeds

- Easy growth

- Employability

- Fertility

- Recycle

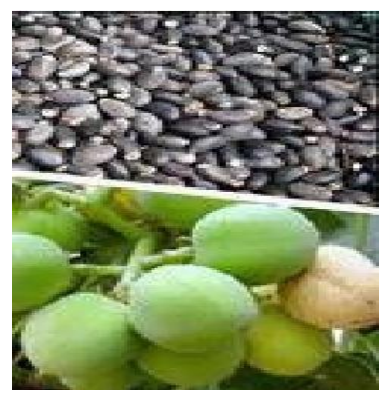

Figure 1: Jatropha Seeds

\section{B. Extracting the Bio-Diesel}

As many researches states that, there are various problems associated with vegetable oils being used as fuel in compression ignition (C.I.) engines, mainly caused by their high viscosity. The high viscosity is due to the large molecular mass and chemical structure of vegetable oils which in turn leads to problems in 1.Pumping of fuel 2.Combustion process 3.Atomization during fuel injection. The high viscosity of vegetable oils and the low volatility affect the atomization and spray pattern of fuel, which leading to 1.Gumming 2.Formation of injector deposits 3.Ring sticking 


\begin{tabular}{|c|c|c|c|c|}
\hline $\mathrm{CH}_{2}-\mathrm{OOC}-\mathrm{R}_{1}$ & & Catalyst & $\mathrm{R}_{1}$-COO-R' & $\mathrm{CH}_{2}-\mathrm{OH}$ \\
\hline $\mathrm{CH}_{2}-\mathrm{OOC}-\mathrm{R}_{2}+$ & $3 \mathrm{R}^{\prime} \mathrm{OH}$ & 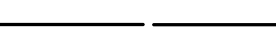 & $\mathrm{R}_{2}$-COO-R' & $+\mathrm{CH}_{2}-\mathrm{OH}$ \\
\hline $\mathrm{CH}_{2}-\mathrm{OOC}-\mathrm{R}_{3}$ & & At Temp 60 to $70^{\circ} \mathrm{C}$ & $\mathrm{R}_{3}-\mathrm{COO}-\mathrm{R}^{\prime}$ & $\mathrm{CH}_{2}-\mathrm{OH}$ \\
\hline Triglyceride & Alcohol & & Esters & Glycerol \\
\hline
\end{tabular}

Figure 2: Trans-Esterification Process

Therefore, a reduction in viscosity is of prime importance to make vegetable oils a suitable alternative fuel for diesel engines. The problem of high viscosity of vegetable oils has been approached in several ways, such as 1 . Blending or dilution with other fuel, 2.Emulsification 3.Transesterification 4. Thermal cracking /Pyrolysis [5]. Among these, the trans-esterification is the commonly used commercial process to produce clean and environmental friendly fuel.

\section{Trans-Esterification Process}

Trans-esterification involves reaction of the triglycerides of Jatropha oil with methyl alcohol in the presence of a catalyst Sodium Hydroxide $(\mathrm{NaOH})$ to produce glycerol and fatty acid ester. The production of biodiesel by transesterification process involves the following sequence steps.

i. Mixing of alcohol and catalyst: For this process, a Specified amount of $450 \mathrm{~mL}$ methanol and $10 \mathrm{gr}$ Sodium Hydroxide $(\mathrm{NaOH})$ was mixed in a round bottom flask.

ii. Reaction: The alcohol/catalyst mix is then charged into a closed reaction vessel and $1000 \mathrm{~mL}$ Jatropha oil is added. Excess alcohol is normally used to ensure total conversion of the fat or oil to its esters.

iii. Separation of glycerin and biodiesel: Once the reaction is complete, two major products exist: glycerin and biodiesel. The quantity of produced glycerin varies according the oil used, the process used, the amount of excess alcohol used. Both the glycerin and biodiesel products have a substantial amount of the excess alcohol that was used in the reaction. The reacted mixture is the oil used, the process used, the amount of sometimes neutralized at this step if needed.

iv. Alcohol Removal: The methanol can be removed by vaporization and this methanol will usually be dry enough to directly recycle back to the reaction [6].

v. Glycerin Neutralization: The glycerin by-product contains unused catalyst and soaps that are neutralized with an acid and sent to storage as crude glycerin. In some cases the salt formed during this phase is recovered for use as fertilizer. In most cases the salt is left in the glycerin. vi. Methyl Ester Wash: The most important aspects of biodiesel production to ensure trouble free operation in diesel engines are complete reaction, removal of glycerin, removal of catalyst, removal of alcohol and absence of free fatty acids.

\section{ENGINE TEST AND RESUlTS}

\section{A. Engine Specifications}

Manufacturer: Kirloskar engines Ltd, Pune, India

No of cylinders: One

No. of strokes: Four

Bore \& Stroke: 80 \& $110 \mathrm{~mm}$

Cooling system: Water

\section{B. Fuel Preparation}

The trans-esterified biodiesel is chemically added with conventional diesel. It is evident that dilution or blending of vegetable oil with other fuels like diesel fuel would bring the viscosity close to a specification range. Therefore, Jatropha oil was blended with diesel oil in varying pro-portions with the intention of reducing its viscosity $[7,8]$. Using this fuel, the engine test is performed in our laboratory for various proportions and the following results have obtained which is shown in tables.

\section{Fuel Properties}

The properties of bio-fuel with various proportions have tabulated by considering Experimental and theoretical values. It is shown in table 1 .

\section{Method of Calculation[9]}

i. Determination of brake power: This engine is a mechanical rope model, so S1 and S2 are noted. By using the following formula brake power is calculated. $\mathrm{N}$ is the speed in rpm. B.P $=\left(2 \pi \mathrm{N}^{*}(\mathrm{~S} 1-\mathrm{S} 2) *(\mathrm{D}+\mathrm{d} / 2) 9.81\right) /(60 * 1000)$

Where $\mathrm{D}$ is diameter of the brake drum

ii. Determination of fuel consumption: Fuel tank is attached with a graduated burette. The valve at the bottom of the tank is closed when fuel consumption rate is to be measured so that fuel is consumed only from the burette. The time taken for ' $x$ ' amount of fuel consumption is recorded to measure the fuel consumption rate. 
$\mathrm{FC}=(\mathrm{x} *$ sp gravity of oil $* 3600) /(1000 *$ time taken $)$

iii. Specific fuel consumption: It is determined from the mass of fuel taken to per $\mathrm{kW}$ brake power.

iv. Determination of brake thermal efficiency:

Brake thermal efficiency $=($ B.PX3600 $) /(\mathrm{mf} * \mathrm{C} . \mathrm{V})$

Where $m_{\mathrm{f}}$ is fuel consumption in $\mathrm{kg} / \mathrm{h}$,
C.V is calorific value of the fuel used in $\mathrm{MJ} / \mathrm{kg}$; Specific fuel consumption was calculated by fuel consumption divided by the rated power output of the engine. The exhaust gas temperature is measured using a digital temperature display.

Table 1: Properties of Bio-Fuel

\begin{tabular}{|c|c|c|c|c|}
\hline S. No & Fuel property & Diesel & $\begin{array}{c}\text { Diesel with } 10 \% \\
\text { Jatropha }\end{array}$ & $\begin{array}{c}\text { Diesel with 20\% } \\
\text { Jatropha }\end{array}$ \\
\hline 1 & Density $\left(\mathrm{kg} / \mathrm{m}^{3}\right)$ & 874 & 889 \\
{$[10]$}
\end{tabular}

Table 2: Test Results with 0\% Jatropha Oil

\begin{tabular}{|c|c|c|c|c|c|c|c|c|c|c|}
\hline \multirow[b]{2}{*}{ S.No } & \multirow[b]{2}{*}{ Speed } & \multicolumn{2}{|c|}{ Load } & \multirow[b]{2}{*}{ h1-h2 } & \multirow{2}{*}{$\mathrm{T}(10 \mathrm{sec})$} & \multirow[b]{2}{*}{$\mathrm{BP}$} & \multirow[b]{2}{*}{$\mathrm{FC}$} & \multirow[b]{2}{*}{ SFC } & \multirow[b]{2}{*}{$\mathrm{B}_{\mathrm{th}}$} & \multirow[b]{2}{*}{ Exhaust } \\
\hline & & $\mathrm{S} 1$ & $\mathrm{~S} 2$ & & & & & & & \\
\hline 1 & 1570 & 0 & 0 & 35 & 75 & 0 & 0.396 & - & 0 & 114 \\
\hline 2 & 1545 & 5 & 6 & 35 & 67 & 0.29 & 0.440 & 1.517 & 5.57 & 141 \\
\hline 3 & 1530 & 7 & 8 & 36 & 50 & 0.58 & 0.590 & 1.017 & 8.32 & 154 \\
\hline 4 & 1525 & 9 & 12 & 37 & 48 & 0.86 & 0.615 & 0.715 & 11.94 & 161 \\
\hline
\end{tabular}

Table 3: Test Results with 10\% Jatropha Oil

\begin{tabular}{|c|c|c|c|c|c|c|c|c|c|c|}
\hline \multirow{2}{*}{ S.No } & \multirow{2}{*}{ Speed } & \multicolumn{2}{|c|}{ Load } & \multirow{2}{*}{ h1-h2 } & \multirow{2}{*}{$\mathrm{T}(10 \mathrm{sec})$} & \multirow[b]{2}{*}{$\mathrm{BP}$} & \multirow[b]{2}{*}{$\mathrm{FC}$} & \multirow[b]{2}{*}{ SFC } & \multirow[b]{2}{*}{$\mathrm{B}_{\mathrm{th}}$} & \multirow[b]{2}{*}{ Exhaust } \\
\hline & & S1 & S2 & & & & & & & \\
\hline 1 & 1570 & 0 & 0 & 40 & 96 & 0 & 0.778 & - & - & 124 \\
\hline 2 & 1560 & 5 & 6 & 38 & 84 & 0.296 & 0.819 & 2.766 & 2.98 & 139 \\
\hline 3 & 1545 & 7 & 9 & 38 & 80 & 0.587 & 0.819 & 1.395 & 5.91 & 158 \\
\hline 4 & 1530 & 9 & 12 & 36 & 69 & 0.872 & 0.865 & 0.991 & 8.31 & 170 \\
\hline
\end{tabular}


Table 4: Test Results with 20\% Jatropha Oil

\begin{tabular}{|c|c|c|c|c|c|c|c|c|c|c|}
\hline \multirow{2}{*}{ S.No } & \multirow{2}{*}{ Speed } & \multicolumn{2}{|c|}{ Load } & \multirow{2}{*}{ h1-h2 } & \multirow{2}{*}{$\mathrm{T}(10 \mathrm{sec})$} & \multirow[b]{2}{*}{$\mathrm{BP}$} & \multirow[b]{2}{*}{ FC } & \multirow[b]{2}{*}{ SFC } & \multirow[b]{2}{*}{$\mathrm{B}_{\mathrm{th}}$} & \multirow[b]{2}{*}{ Exhaust } \\
\hline & & S1 & S2 & & & & & & & \\
\hline 1 & 1570 & 0 & 0 & 41 & 87 & 0 & 0.359 & - & - & 127 \\
\hline 2 & 1550 & 5 & 6 & 38 & 81 & 0.294 & 0.385 & 1.309 & 6.37 & 143 \\
\hline 3 & 1545 & 7 & 9 & 37 & 68 & 0.587 & 0.459 & 0.781 & 10.68 & 161 \\
\hline 4 & 1535 & 9 & 12 & 37 & 64 & 0.870 & 0.488 & 0.560 & 14.89 & 175 \\
\hline
\end{tabular}

BP-Brake power, FC-Fuel consumption, SFC-Specific fuel Consumption, Bth-Brake thermal efficiency

\section{RESULTS AND DISCUSSION}

The following result is obtained while testing with single cylinder four stroke diesel engines by biodiesel and diesel.

\section{A. Performance Characteristics}

\section{i. $\quad$ SFC Variation with Brake Power}

The fig:3 indicate the variation of specific fuel consumption with brake power. According to the result obtained, the optimized blend is found to be B20 oil. This provides better fuel consumption data compared to others.

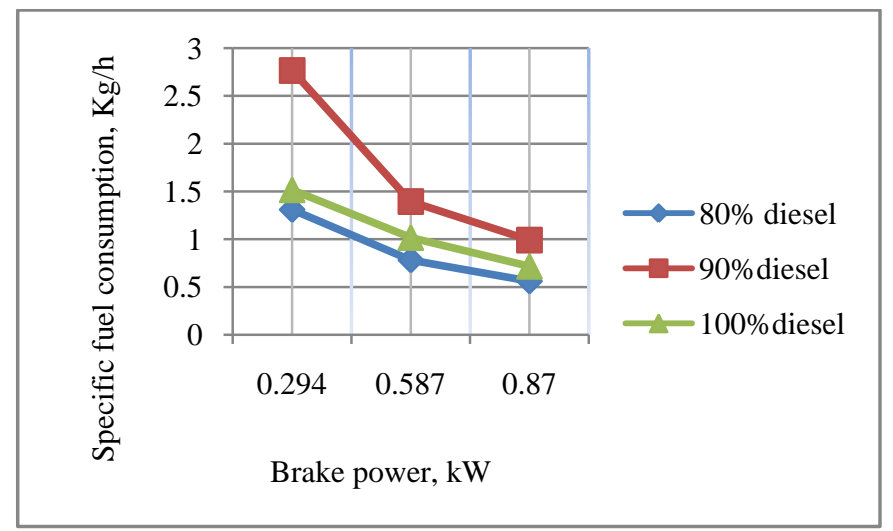

Figure 3: Variation of SFC with BP

ii. Brake power with Thermal Efficiency

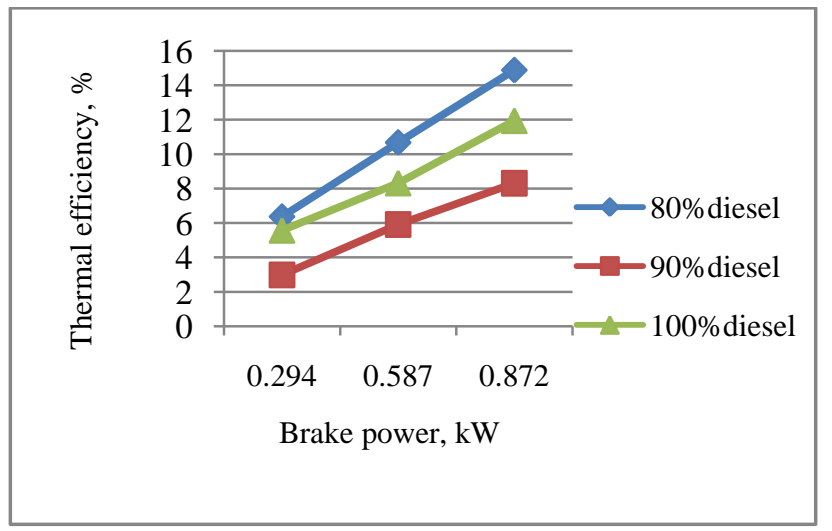

Figure 4: Variation of Efficiency with BP

The fig: 4 indicate variation of efficiency with brake power obtained. Brake thermal efficiency is defined as actual brake work per cycle divided by the amount of fuel chemical energy as indicated by lower heating value of fuel [11]. The brake thermal efficiency with biodiesel and its blends was found to be slightly higher than that of diesel fuel at tested load conditions. Efficiency of the blend is increased while using optimized proportion, i.e. diesel with 20\% Jatropha.

\section{iii. Exhaust Temperature Variation with BP}

Fig: 5 indicate increase in exhaust temperature with brake power. Exhaust gas temperature plays a vital role in increasing NOx emission. The only drawback getting from the Jatropha oil is increased NOx emissions. That can be also minimized by finding proper proportions fuels.

\section{B. Emission Characteristics}

The emissions characteristics are theoretically studied and the results are obtained as follows. Fig. 6 shows the variation of NOx with respect to brake power [12]. At higher power output conditions, due to higher peak and exhaust temperatures the NOx values are relatively higher compared to low power output conditions. A slight increase in NOx is observed for blends of Esterified Jatropha Diesel compare to diesel. The reason may be due to late burning of blends of MEJ-Diesel during expansion [13].

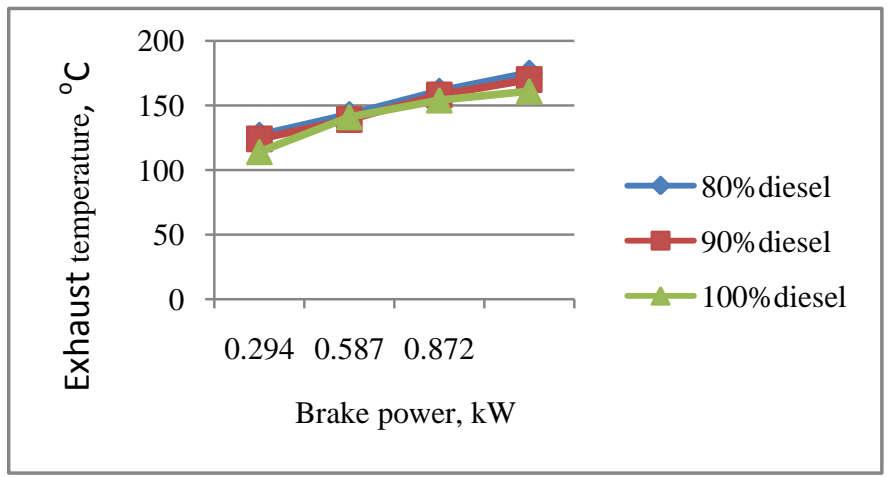

Figure 5: Variation of Exhaust Temperature with BP 


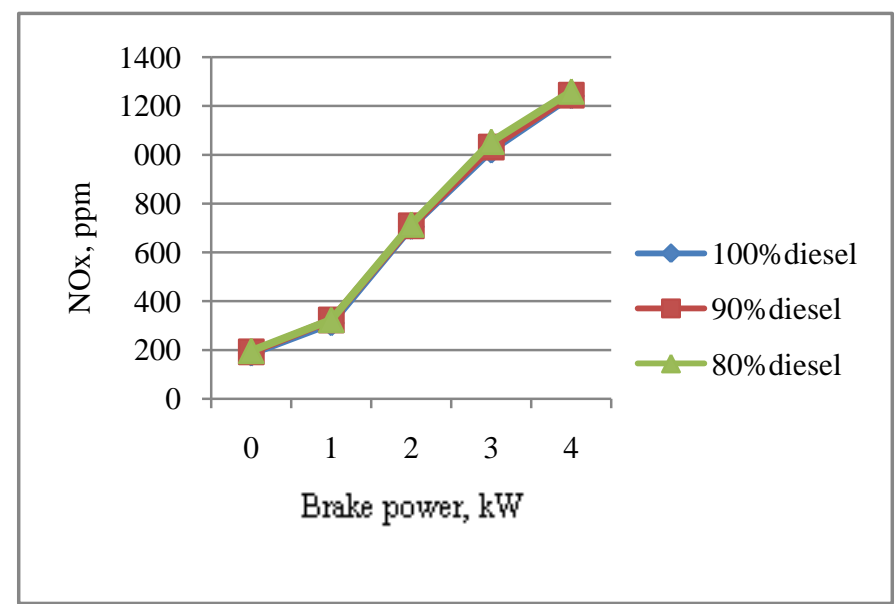

Figure 6: Variation of NOx with BP

The carbon dioxide emission from the diesel engine with different blends is shown in Fig. 7, [12]. The $\mathrm{CO} 2$ increased with increase in load conditions for diesel and for biodiesel blended fuels. The carbon dioxide emission from the diesel engine with different blends is shown in Fig. 7. The $\mathrm{CO} 2$ increased with increase in load conditions for diesel and for biodiesel blended fuels. The Jatropha biodiesel followed the same trend of $\mathrm{CO} 2$ emission, which was higher than in case of diesel. The $\mathrm{CO} 2$ in the exhaust gas was same for Jatropha biodiesel blended fuels and Jatropha biodiesel.

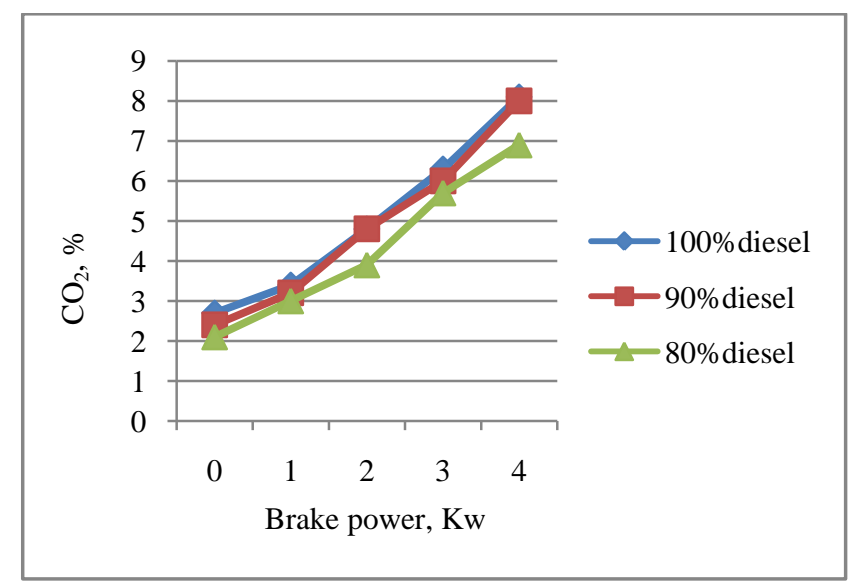

Figure 7: Variation of $\mathrm{CO}_{2}$ with $\mathrm{BP}$

The $\mathrm{CO}$ emission from the diesel fuel with biodiesel blended fuels and biodiesel is shown in Fig. 8, [14]. The CO reduction by biodiesel was $17.5,17,16,14$ and 14 per cent at $1,1.5,2,2.5$ and $3.5 \mathrm{~kW}$ load conditions [9].

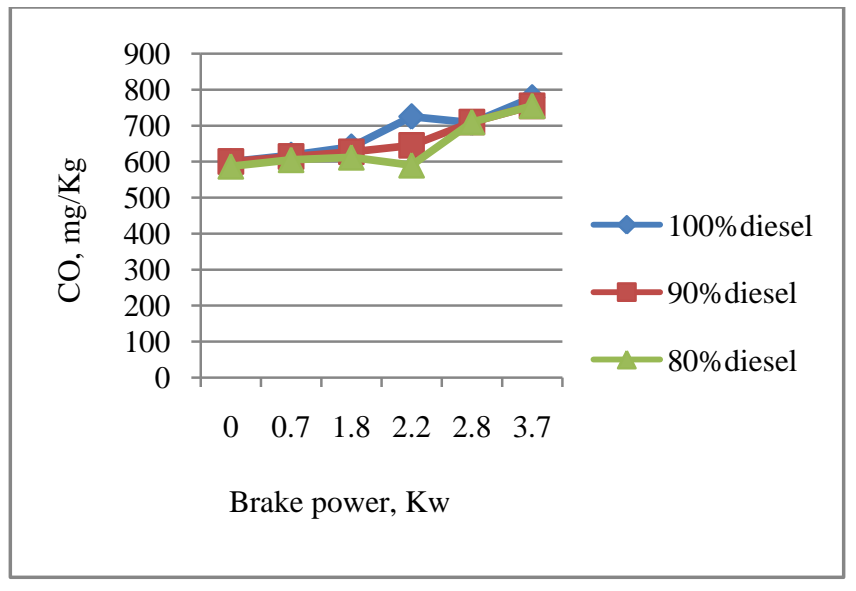

Figure 8: Variation of $\mathrm{CO}$ with $\mathrm{BP}$

Similar results were obtained for biodiesel blended fuels and Jatropha biodiesel with lower emission than diesel fuel.

\section{SUITABILITY CRITERIA}

\section{A. Optimized Blend}

It is evident that blending of trans-esterified vegetable oil with the conventional diesel fuel would bring the viscosity close to diesel. Considering the various results obtained from engine test, using Jatropha oil blend instead of diesel fuel is not beneficial. Finding the proper proportions of these combinations is essential. This may have little disappointments with various types of engines. According to my test rig, addition of $20 \%$ Jatropha oil is suitable and eco friendly one. This is considered to be an optimized blend.

\section{B. Injection Pressure}

Fig: 9 indicate the variation of SFC with injection pressure, in which B20 providing greater result [15]. When the injection pressure is increased up to a certain level the thermal efficiency also increased. This pressure is considered to be optimum level which has monitored that 200-220 bar. For B20 blend 200bar is suitable IP level.

\section{Injection Temperature}

The dynamic and kinematic viscosity decreased exponentially as rising of the fuel temperature or preheating. This viscosity is monitored and calculated from various models, [16] in terms of oil stability index which gives various values with temperature as shown in fig: 11 . From this we may consider that reducing OSI (oil stability index) provides better results. [17] Reported that by using a heat exchanger, preheated Jatropha oil has the potential to be a substitute fuel for diesel engines. 


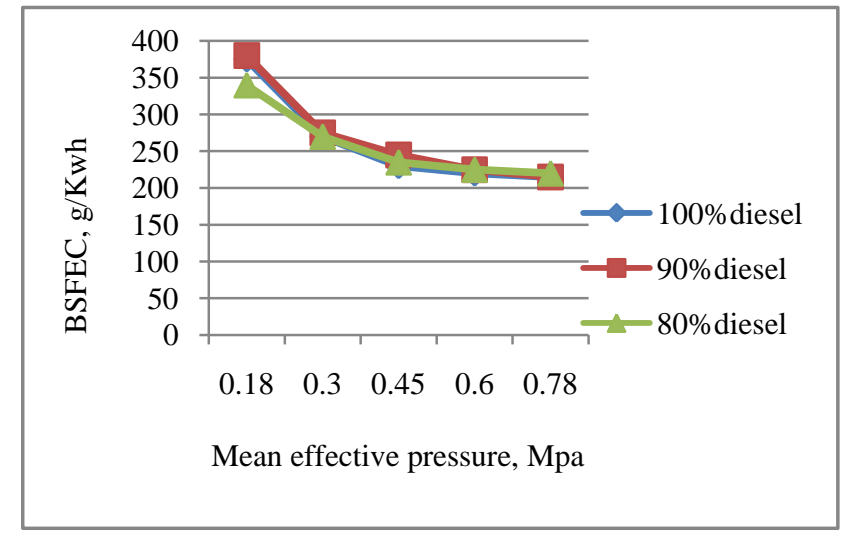

Figure 9: Variation of BSFC with Pressure

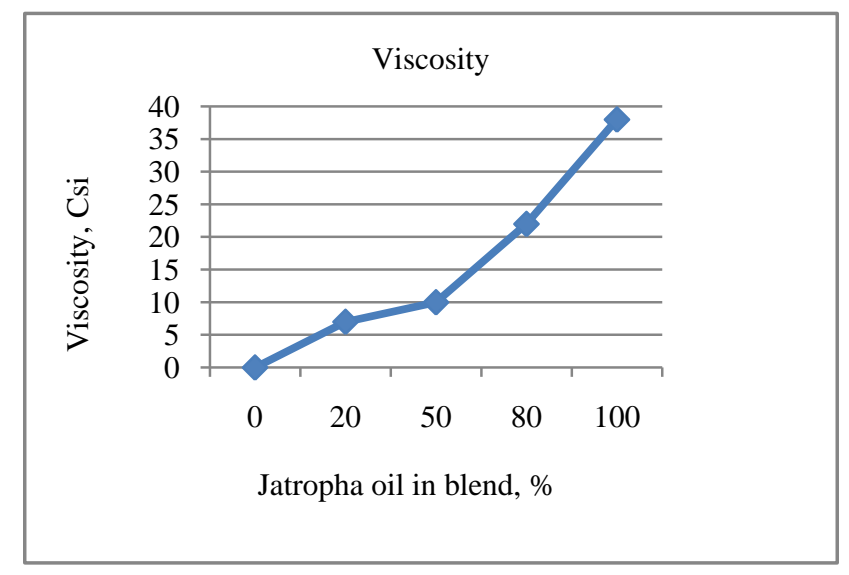

Figure 10: Variation of Viscosity with Blend

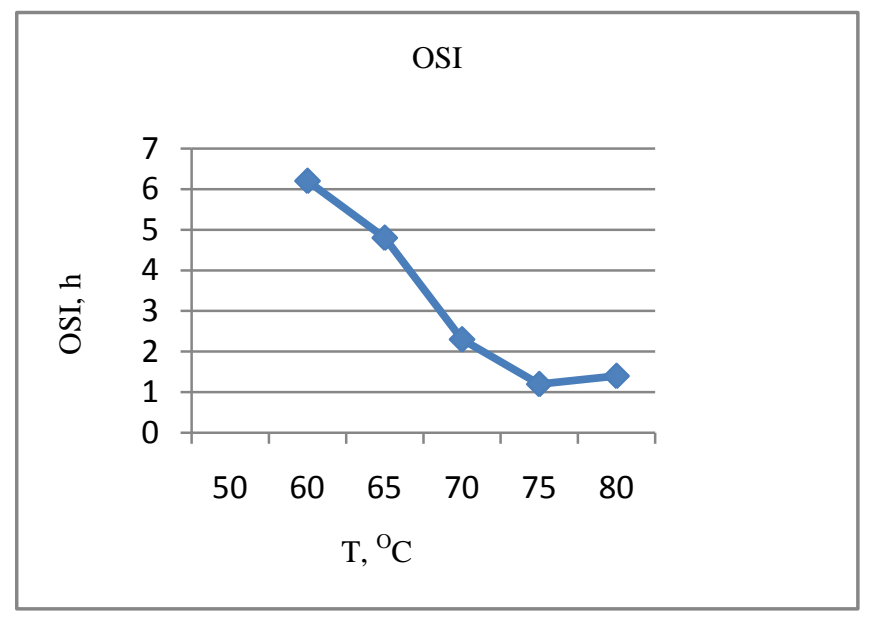

Figure 11: Variation of OSI with Temperature

Fig 10 indicates the variation of viscosity for different blend of Jatropha bio-diesel. From this we may consider the suitable proportion of Jatropha and diesel oil. Increasing the Jatropha proportion leads to higher viscosity of fuel.

\section{Atomization Process}

This is the process which breaks the higher bonded molecules to lower or smaller molecules results in reduced viscosity. It essentially depends on the injection pressure and injection nozzle. Reducing the diameter of injection nozzle with increased pressure will produce fine distribution of fuel.
The diameter of the nozzle may recommend as small as $0.1 \mathrm{~mm}[14]$.

\section{CONCLUSION}

Bio-oil production from Jatropha seeds, its fuel Properties, characterization, and an experimental investigation were conducted to explore the performance of Jatropha oil and blends as a diesel alternative. From The results we may concluded that,

- Jatropha oil is found to be a promising alternative fuel for CI engines. It can be used for blending up to $20 \%$ Jatropha oil without any reduction in thermal efficiency. According my test rig, $20 \%$ blend is the optimum level of bio-product.

- Emissions of $\mathrm{CO} 2$ with Jatropha oil blends up to moderate loads are lower than that with diesel fuel.

- Emissions of CO with Jatropha oil and blends are much lower than diesel at all loading conditions, although the engine always ran leaner with Jatropha oil and blends than diesel.

- Engine test with pure Jatropha oil at proper fuel injection pressures (200-220bar) with a smaller nozzle hole to improve atomization. This also improves in homogeneity of local air fuel mixture.

- Using biodiesel reduces pollutions except the NOx emissions. NOx emissions also can be reduced with the optimized proportions of Jatropha oil and diesel. Finding the suitable parameters for engine characteristics leads to efficient usage of bio-diesel as alternate fuel.

- This methyl ester of Jatropha oil along with diesel may reduce the environmental impacts of transportation, reduce the dependency on crude oil imports, and offer business possibilities to agricultural enterprises for periods of excess agricultural production. On the whole it is concluded that the methyl ester of Jatropha oil will be a good alternative fuel for diesel engine for agricultural applications.

\section{REFERENCES}

[1] G.M. Gubitz, M. Mittelback and M. Trabi "Bio-fuels and industrial products from Jatropha curcas", ISBN 3-7041-0243, 1997.

[2] Emil Akbar, Zahira Yaakob, Siti Kartom Kamarudin, Manal Ismail and Jumat Salimon, "Characteristic and Composition of Jatropha Curcas Oil Seed from Malaysia and its Potential as Biodiesel Feedstock", European Journal of Scientific Research, Volume 29, No. 3, Pp.396-403, ISSN: 1450-216X, 2009.

[3] J. Narayana Reddy and A. Ramesh, "Parametric studies for improving the performance of a Jatropha oil-fuelled compression ignition engine", Renewable Energy, Volume 31, Pp. 1994-2016, 2006.

[4] C. Namasivayam, D. Sangeetha, and R. Gunasekaran, "Removal of anions, heavy metals, organics and dyes from water by adsorption onto a new activated carbon from Jatropha husk, an agro-industrial solid waste", Process Safety and Environmental Protection, Volume 85, Pp. $181-184,2007$

[5] K. Pramanik, "Properties and use of jatropha curcas oil and diesel fuel blends in compression ignition engine", Renewable Energy, Volume 28, No. 2, Pp. 239-248, 2003.

[6] Kazi mostafijur rahman, Mohammad mashud, Md. Roknuzzaman and Asadullah al Galib, "Biodiesel from jatropha oil as an alternative fuel for 
diesel engine", International Journal of Mechanical \& Mechatronics IJMME-IJENS, Volume 10, No. 03.

[7] A.K. Agarwal, "Vegetable oils verses diesel fuel: development and use of biodiesel in a compression ignition engine", TIDE, Volume 8, No. 3, Pp.191-204, 1998

[8] S. Sinha, N.C. Misra, "Diesel fuel alternative from vegetable oil, Chemical Engineering World, Volume 32, No. 10, Pp.77-80, 1997

[9] Y.V. Hanumantha Rao1, Ram Sudheer Voleti1, A.V.Sitarama Raju2 and P.Nageswara Reddy, "Experimental investigations on jatropha biodiesel and additive in diesel engine", Indian Journal of Science and Technology, Volume 2, No. 4, ISSN: 0974-6846, 2009.

[10] R.K.Singh and Saroj K.Pathi, "Characterization of Jatropha oil for the preparation of bio-diesel" National product radiance, Volume 8, No. 2, Pp 127-132,2009.

[11] M. Senthil Kumar, A. Ramesh and B. Nagalingam, "An experimental comparison of methods to use methanol and jatropha oil in a compression ignition engine" Biomass and Bioenergy Journal. Volume 25, Pp.309-318, 2003

[12] T. Elango and T. Senthilkumar, "Performance and emission characteristics of $\mathrm{CI}$ engine fuelled with non edible vegetable oil and diesel blends", Journal of Engineering Science and Technology, Volume 6, No. 2, Pp. 240-250, 2011.

[13] R. Forgiel and K.S. Varde "Experimental investigation of vegetable oil utilization in a direct injection diesel engine". SAE Alternate fuels for diesel engines, SP 500 fuels and lubricants meeting Tulsa, 1981

[14] Vijittra Chalatlon, Murari Mohon Roy, Animesh Dutta and Sivanappan Kumar, "Jatropha oil production and an experimental investigation of its use as an alternative fuel in a DI diesel engine", Journal of Petroleum Technology and Alternative Fuels, Volume 2, No. 5, Pp. 76-85, 2011.

[15] X-G Wang, B Zheng, Z-H Huang, N Zhang, Y-J Zhang, and E-J Hu, "Performance and emissions of a turbocharged,high-pressure common rail diesel engine operating on biodiesel/diesel blends", Automobile Engineering, Volume 225, 2010.

[16] Robert O. Dunn, "Effect of Temperature on the Oil Stability Index (OSI) of Biodiesel", Energy \& Fuels, Volume 22, Pp. 657-662, 2008

[17] B.S. Chauhan, N. Kumar, Y.D. Jun, K.B. Lee, "Performance and emission study of preheated Jatropha oil on medium capacity diesel engine”, Energy, Volume 35, Pp. 2484-2492, 2010 